\title{
Toxic metals in cord blood and later development of Type 1 diabetes
}

\author{
Ludvigsson $\mathrm{J}^{1 *}$, Andersson-White $\mathrm{P}^{2}$ and Guerrero-Bosagna $\mathrm{C}^{3}$ \\ ${ }^{1}$ Department of Clinical and Experimental Medicine, Division of Pediatrics, Linköping University, Linköping, Sweden \\ ${ }^{2}$ Crown Princess Victoria Children's Hospital, Region Östergötland. Linköping Sweden \\ ${ }^{3}$ IFM Biology, Linköping, University; Linköping university, Linköping, Sweden
}

\begin{abstract}
The incidence of type 1 diabetes (T1D) has increased explained by changes in environment or lifestyle. In modern society dissemination of heavy metals has increased. As the autoimmune process usually starts already, we hypothesized that exposure to toxic metals during fetal life might contribute to development of T1D in children.

We analysed arsenic $(\mathrm{AS})$, aluminium $(\mathrm{Al})$, cadmium $(\mathrm{Cd})$, lithium $(\mathrm{Li})$, mercury $(\mathrm{Hg})$, lead $(\mathrm{Pb})$, in cord blood of 20 children who later developed T1D (probands), and in 40 age-and sex-matched controls. Analysis of heavy metals in cord blood was performed by ALS Scandinavia AB (Luleå, Sweden) using the 'ultrasensitive inductively coupled plasma sector field mass spectrometry method' (ICP-SFMS) after acid digestion with $\mathrm{HNO}_{3}$.

Most children had no increased concentrations of the metals in cord blood. However, children who later developed T1D had more often increased concentrations (above limit of detection; LOD) of aluminium ( $\mathrm{p}=0.006)$ in cord blood than the non-diabetic controls, and also more often mercury and arsenic (n.s).

Our conclusion is that exposure to toxic metals during pregnancy might be one among several contributing environmental factors to the disease process if confirmed in other birth cohort trials.
\end{abstract}

\section{Introduction}

The incidence of type 1 diabetes (T1D) has increased over decades. This must be explained by changes in environment or lifestyle, but the aetiology is unknown [1]. As the autoimmune process often starts very early in life the pathogenic factors might be found in fetal life. In modern society dissemination of heavy metals and human exposure has increased, which has been associated to T1D. Some minerals which part of the normal physiology may play a role. Thus, it is known that iron may be toxic for beta cells and studies suggest that increased iron consumption in nutrients may be associated with increased risk of T1D [2]. It has also been found that high iron concentrations at birth is associated with an increased risk of T1D [3]. Deficiency of zinc, a central part of the insulin hexamer, is regarded to be related to increased risk of diabetes and there are also epidemiological studies supporting a role for low zinc in the risk for T1D [4] while low perinatal zinc status was not associated with the risk of T1D later in children [5]. However, metals that have no physiological role in the human physiology but should rather be regarded as toxic, may play a role. Thus arsenic, cadmium, mercury and nickel have been found to have toxic effect on beta cell function [6], and cadmium concentration to be higher in urine of prediabetic and diabetic patients than of controls [7]. In animal studies cadmium may cause beta cell destruction. High concentration of nitrate as well as mercury and arsenic in drinking water has been suspected to increase the risk of developing type 1 diabetes [8]. Thus, heavy metals in foods or water might influence the autoimmune mechanisms in genetically susceptible individuals, and exposure to toxins might result in pancreatic islet cell death.

With this background, and the fact that the autoimmune process usually starts already in infants we hypothesized that exposure to toxic heavy metals during fetal life might in some way contribute to later development of that process which leads to T1D in children.

\section{Material and methods}

ABIS (All Babies in Southeast Sweden) is a cohort trial with children born Oct $1^{\text {st }} 1997$ - Oct $1^{\text {st }} 1999$ followed prospectively from birth with the aim to study causes of immune-mediated diseases in a general population [9]. We chose randomly 20 children (probands) among those who have developed T1D and in addition 40 age and sex-matched controls, who have remained non-diabetic. Parents or guardians gave their informed consent and the protocol of the ABIS study was approved by the Research Ethics Committees of the Faculty of Health Sciences, Linköping University, and the Medical Faculty, Lund University, Sweden 1997-02-19 Dnr 96287.

The following metals were analysed in cord blood of 20 probands and in 40 controls (arsenic only in 10 controls): arsenic (AS), aluminium (Al), cadmium $(\mathrm{Cd})$, lithium $(\mathrm{Li})$, mercury $(\mathrm{Hg})$, lead $(\mathrm{Pb})$. Analysis of heavy metals in cord blood was performed by ALS Scandinavia AB (Luleå, Sweden) using the 'ultrasensitive inductively coupled plasma sector field mass spectrometry method' (ICP-SFMS) after acid digestion with $\mathrm{HNO}_{3}$, according to the standards ISO 17294-1 (https://www.iso.

${ }^{*}$ Correspondence to: Johnny Ludvigsson, Crown Princess Victoria Children's Hospital, University Hospital, SE-581 85, Linköping, Sweden, Tel: +4613 2868 54; E-mail: Johnny.Ludvigsson@liu.se

Key words: type 1 diabetes, toxic metals, aetiology, ABIS, children

Received: May 02, 2019; Accepted: May 20, 2019; Published: May 23, 2019 
org/standard/32957.html) and 2 (https://www.iso.org/standard/62962. html), and the EPA Method 200.8 (https://www.epa.gov/homelandsecurity-research/epa-method-2008-determination-trace-elementswaters-and-wastes) [10].

\section{Statistical analysis}

Data were found to be left censored for all metals with a large percentage of cases with values below the limit of detection (LOD) making analysis with parametric test unsuitable. Instead the distribution of values above or below LOD for respective metal was compared and tested using Chi-square test of independence or Fischer's exact test when cell count was found to be below 5 . Data was analyzed with SPSS version 23.0 .

\section{Results}

Concentrations of the metals in cord blood in the probands and the controls are seen in Table 1. Most of the children, both probands and controls, had no increased concentrations of the metals in cord blood. However, children who later developed T1D had significantly more often increased concentrations (above limit of detection; LOD) of aluminium in cord blood than the non-diabetic controls $(p=0.006)$. There was no significant difference between the groups for any other single metal, but both mercury and arsenic were more common (n.s) in the probands (Figure 1). Those who developed T1D later had significantly more often increased concentrations of the combination of aluminium and arsenic.

\section{Discussion}

In a prospective study with water quality measured before the onset of islet autoimmunity and T1D, concentrations of nitrate, nitrite, iron, aluminium, and manganese were not found to be associated with risk of T1D progression [11]. However, as mentioned above there are indications that heavy non-physiological metals may have toxic effects on beta cells [6] and exposure to such metals has been suspected to increase the risk of developing type 1 diabetes [8] but we know of no published studies where exposure to toxic metals during pregnancy has been analyzed.

Here we found that aluminium more often was increased above the level of detection in cord blood of children who later develop T1D. Aluminium has to our knowledge not been previously associated to T1D but been discussed as a possible risk factor for neurological diseases such as autism [11]. We also found mercury and arsenic slightly more often in cord blood of children who later develop T1D. Mercury is supposed to influence the immune system and could contribute to the development of autoimmune diseases [12]. The cells and organ systems can be supposed to be more sensitive to toxic agents during the very early fetal life, and therefore our findings is an observation that should be studied further.

A limitation of our study is of course the low numbers. This might explain that some differences seen between exposure to mercury and arsenic do not become statistically significant, but it is then even more remarkable that we see statistically significant differences in

Table 1. Distribution of metal concentration above the limit of detection in cord blood at birth in diabetic patients and controls. Limit of detection for each metal; Aluminium $7.0 \mu \mathrm{g} / \mathrm{l}$, Cadmium $0.07 \mu \mathrm{g} / 1$, Lithium $1.0 \mu \mathrm{g} / \mathrm{l}$, Mercury $0.3 \mu \mathrm{g} / \mathrm{l}$, Lead $0.7 \mu \mathrm{g} / \mathrm{l}$, Arsenic $1.0 \mu \mathrm{g} / 1$.

\begin{tabular}{|c|c|c|c|c|}
\hline & $\begin{array}{c}\text { Controls } \\
(\%)\end{array}$ & $\begin{array}{c}\text { Type } 1 \text { Diabetes } \\
\text { (\%) }\end{array}$ & $\begin{array}{c}\text { Total } \\
(\%)\end{array}$ & $p$ \\
\hline Aluminium (Al) & $\begin{array}{c}2 \\
(5.4 \%)\end{array}$ & $\begin{array}{c}7 \\
(35.0 \%)\end{array}$ & $\begin{array}{c}9 \\
(15.8 \%)\end{array}$ & $0.006^{\mathrm{a}}$ \\
\hline Cadmium (Cd) & $\begin{array}{c}5 \\
(12.5 \%)\end{array}$ & $\begin{array}{c}1 \\
(5.0 \%)\end{array}$ & $\begin{array}{c}6 \\
(10.0 \%)\end{array}$ & $0.653^{\mathrm{a}}$ \\
\hline Lithium (Li) & $\begin{array}{c}3 \\
(7.7 \%)\end{array}$ & $\begin{array}{c}0 \\
(0.0 \%)\end{array}$ & $\begin{array}{c}3 \\
(5.1 \%)\end{array}$ & $0.544^{\mathrm{a}}$ \\
\hline Mercury (Hg) & $\begin{array}{c}5 \\
(12.5 \%)\end{array}$ & $\begin{array}{c}5 \\
(25 \%) \\
\end{array}$ & $\begin{array}{c}10 \\
(16.7 \%)\end{array}$ & $0.278^{\mathrm{a}}$ \\
\hline Lead $(\mathrm{Pb})$ & $\begin{array}{c}5 \\
(12.5 \%)\end{array}$ & $\begin{array}{c}1 \\
(5.0 \%)\end{array}$ & $\begin{array}{c}6 \\
(10.0 \%)\end{array}$ & $0.653^{\mathrm{a}}$ \\
\hline Arsenic (As) & $\begin{array}{c}1 \\
(10.0 \%)\end{array}$ & $\begin{array}{c}6 \\
(30 \%)\end{array}$ & $\begin{array}{c}7 \\
(23.3 \%)\end{array}$ & $0.372^{\mathrm{a}}$ \\
\hline Any metal* & $\begin{array}{c}16 \\
(43.2 \%\end{array}$ & $\begin{array}{c}10 \\
(50.0 \%)\end{array}$ & $\begin{array}{c}26 \\
(45.6 \%)\end{array}$ & $0.625^{\mathrm{b}}$ \\
\hline Any $\geq 2$ metals* & $\begin{array}{c}3 \\
(8.1 \%)\end{array}$ & $\begin{array}{c}3 \\
(15.0 \%)\end{array}$ & $\begin{array}{c}6 \\
(10.5 \%)\end{array}$ & $0.654^{\mathrm{a}}$ \\
\hline Any 3 metals* & $\begin{array}{c}1 \\
(2.7 \%)\end{array}$ & $\begin{array}{c}1 \\
(5.0 \%)\end{array}$ & $\begin{array}{c}2 \\
(3.5 \%)\end{array}$ & $1.00^{\mathrm{a}}$ \\
\hline Any metal** & $\begin{array}{c}17 \\
(45.9 \%\end{array}$ & $\begin{array}{c}13 \\
(65.0 \%)\end{array}$ & $\begin{array}{c}30 \\
(52.6 \%)\end{array}$ & $0.169^{b}$ \\
\hline Any $\geq 2$ metals** & $\begin{array}{c}3 \\
(8.1 \%)\end{array}$ & $\begin{array}{c}4 \\
(20.0 \%)\end{array}$ & $\begin{array}{c}7 \\
(12.3 \%)\end{array}$ & $0.226^{\mathrm{a}}$ \\
\hline Any 3 metals** & $\begin{array}{c}1 \\
(2.7 \%)\end{array}$ & $\begin{array}{c}3 \\
(15.0 \%)\end{array}$ & $\begin{array}{c}4 \\
(7.0 \%)\end{array}$ & $0.119^{\mathrm{a}}$ \\
\hline $\mathrm{Al}$ and $\mathrm{Hg}$ & $\begin{array}{c}0 \\
(0 \%)\end{array}$ & $\begin{array}{c}2 \\
(10 \%)\end{array}$ & $\begin{array}{c}2 \\
(3.5 \%)\end{array}$ & $0.119^{\mathrm{a}}$ \\
\hline As and $\mathrm{Hg}$ & $\begin{array}{c}0 \\
(0.0 \%)\end{array}$ & $\begin{array}{c}3 \\
(15.0 \%)\end{array}$ & $\begin{array}{c}3 \\
(5.0 \%)\end{array}$ & $0.033^{\mathrm{a}}$ \\
\hline $\mathrm{Cd}$ and $\mathrm{Pb}$ & $\begin{array}{c}2 \\
(5 \%)\end{array}$ & $\begin{array}{c}1 \\
(5 \%)\end{array}$ & $\begin{array}{c}3 \\
(5 \%)\end{array}$ & 1.00 \\
\hline \multicolumn{5}{|c|}{$\begin{array}{l}\text { a'Fischer's Exact test } \\
\text { b Chi-square test } \\
\text { *Arsenic not included } \\
\text { ** Including known values for Arsenic. Missing values for Arsenic are assumed to be below detection }\end{array}$} \\
\hline
\end{tabular}



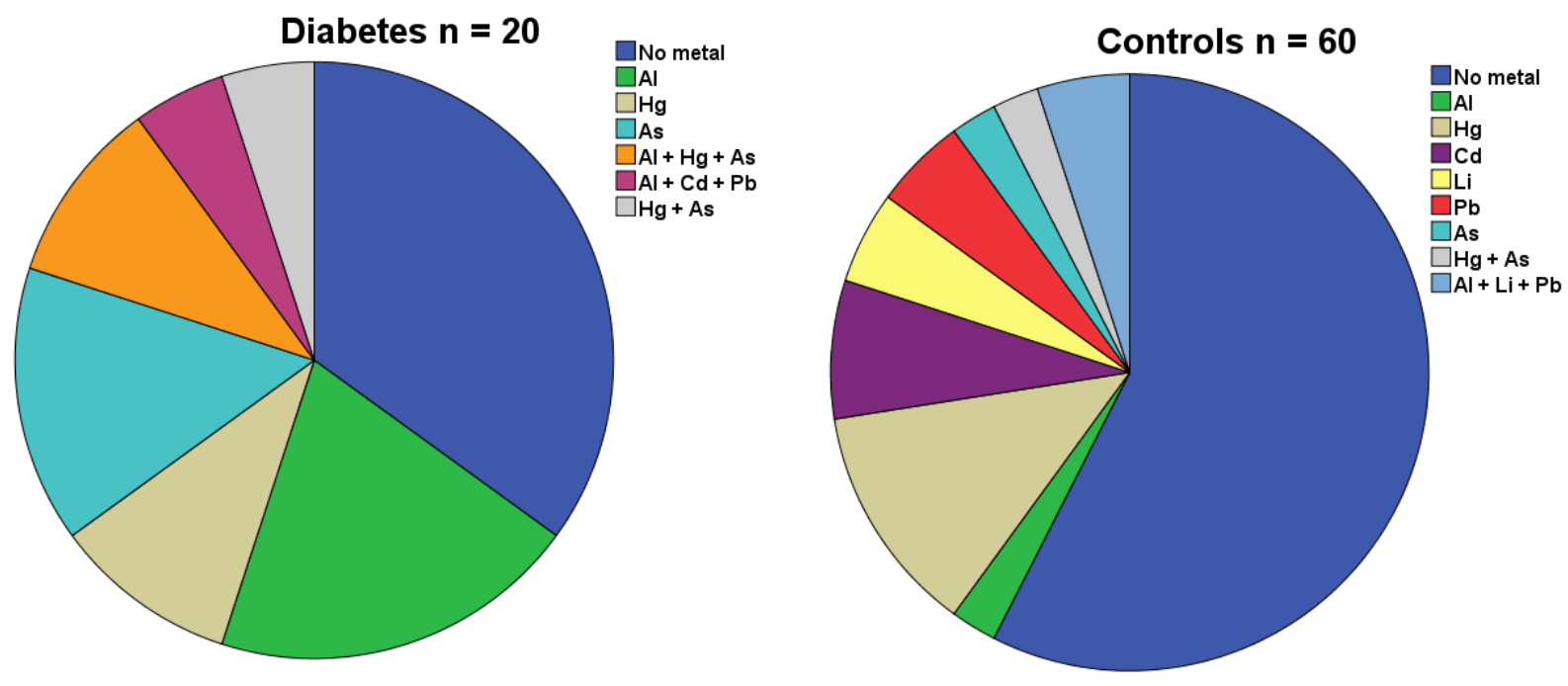

Figure 1. Children who later developed Type 1 diabetes $(\mathrm{n}=20)$ have more often one or more toxic metals detectable in their cord blood than what is found in cord-blood of control children, born very close in time, who remain non-diabetic.

prevalence of toxic metals in cord blood. As several individuals have a high number of measures below the limit of detection a more correct statistical approach to use might have been a zero-inflated model, but our numbers do not allow this.

In conclusion, in most of the cord blood samples in children who later develop T1D we do not find any increase of toxic metals and such exposure therefore does not seem to be of common or heavy importance. It is necessary to be cautious drawing conclusions from our small material, but we find more often increased concentrations of aluminium and, although non-significantly, also more often mercury and arsenic in cord blood of children who later develop T1D compared to what is found in nondiabetic controls. These findings suggest that exposure to toxic metals during pregnancy might be one among several contributing environmental factors to the disease process if confirmed in other studies [13].

\section{Conflict of interest}

The authors have no conflicts of interest to disclose.

\section{Financial disclosure}

The authors have no financial relationships relevant to this article to disclose

\section{Acknowledgments}

We are grateful to all children and parents who participated in the ABIS study, as well as to the obstetric clinics and well-baby clinics who helped with the collection of samples. We would also like to thank a large number of nurses and staff at KEF (laboratory), to some extent partly supported by Grant: U01HD040364-15 to the NIH, especially Ingela Johansson for skillful job. The ABIS study has been supported by Barndiabetesfonden (The Swedish Child Diabetes Foundation), JDRF Wallenberg Foundation (K 98-99D-12813-01A), Research council of Southeast Sweden (FORSS), Östgöta Brandstodsbolag, Swedish Research Council K2005-72X-11242-11A, and ALF/County Council of Östergötland.

\section{References}

1. Rewers M, Ludvigsson J (2016) Environmental risk factors for type 1 diabetes. Lancet 387: 2340-2348. [Crossref]
2. Søgaard KL, Ellervik C, Svensson J, Thorsen SU (2017) The Role of Iron in Type 1 Diabetes Etiology: A Systematic Review of New Evidence on a Long-Standing Mystery. Rev Diabet Stud 14: 269-278. [Crossref]

3. Kyvsgaard JN, Overgaard AJ, Thorsen SU, Hansen TH, Pipper CB, et al. (2017) High Neonatal Blood Iron Content Is Associated with the Risk of Childhood Type 1 Diabetes Mellitus. Nutrients 6: 11 [Crossref]

4. Valera P, Zavattari P, Sanna A, Pretti S, Marcello A, et al. (2015) Zinc and Other Metals Deficiencies and Risk of Type 1 Diabetes: An Ecological Study in the High Risk Sardinia Island. PLoS One 10: e0141262 [Crossref]

5. Kyvsgaard JN, Overgaard AJ, Jacobsen LD, Thorsen SU, et al. (2017) Low perinata zinc status is not associated with the risk of type 1 diabetes in children. Pediatr Diabetes 18: 637-642. [Crossref]

6. Chen YW, Yang CY, Huang CF, Hung DZ, Leung YM, et al. (2009) Heavy metals, islet function and diabetes development. Islets 1: 169-176 [Crossref]

7. Schwartz GG, Il'Yasova D, Ivanova A (2003) Urinary cadmium, impaired fasting glucose, and diabetes in the NHANES III. Diabetes Care 26: 468-470. [Crossref]

8. Samuelsson U, Oikarinen S, Hyoty H, Ludvigsson J (2011) Low zinc in drinking water is associated with the risk of type 1 diabetes in children. Pediatric Diabetes 12: 156164. [Crossref]

9. Ludvigsson J, Ludvigsson M, Sepa A (2001) Screening for prediabetes in the genera child population: maternal attitude to participation. Pediatr Diabetes 2: 170-174. [Crossref]

10. Planchon F, Boutron CF, Barbante C (2001) Ultrasensitive determination of heavy metals at the sub-picogram per gram level in ultraclean Antarctic snow samples by inductively coupled plasma sector field mass spectrometry. Analytica Chimica Acta 450: 193-205.

11. Winkler C, Mollenhauer U, Hummel S, Bonifacio E, et al. (2008) Exposure to environmental factors in drinking water: risk of islet autoimmunity and type 1 diabetes-the BABYDIAB study. Horm Metab Res 40: 566-571. [Crossref]

12. Tomljenovic L, Shaw CAJ (2011) Do aluminum vaccine adjuvants contribute to the rising prevalence of autism? Inorg Biochem 105: 1489-1499. [Crossref]

13. Crowe W, Allsopp PJ, Watson GE, Magee PJ, Strain JJ, et al. (2017) Mercury as an environmental stimulus in the development of autoimmunity - A systematic review. Autoimmun Rev 16: 72-80. [Crossref]

Copyright: (C2019 Jiménez-Castillo E. This is an open-access article distributed under the terms of the Creative Commons Attribution License, which permits unrestricted use, distribution, and reproduction in any medium, provided the original author and source are credited. 